INTERNATIONAL JOURNAL OF
ORGANIZATIONAL LEADERSHIP
ORAGANIZATIONAL
IEAERSHIP

\title{
Shared Leadership and Organizational Resilience: A Systematic Literature Review
}

\author{
Jotham Mukundi Gichuhi
}

School of leadership, Business and technology, Pan Africa Christian University, Nairobi, Kenya

\section{Keywords: \\ Shared Leadership, Organizational resilience, \\ Disaster Management}

\section{Received}

18 May 2021

Received in revised form

21 June 2021

Accepted

24 June 2021

*Correspondence:

jgichuhi@ajglobalconsult.com

\begin{abstract}
For a long time, leadership has been viewed as a 'great man' construct where an individual has the power, qualities, and position to influence others towards the achievement of a given goal or objective. However, that has changed. Heroic leadership can no longer meet the expectations being placed on leadership. Today's organizations are also faced with drastically changing trends and turbulent landscapes. This has emphasized the need for top-notch leadership to guarantee organizational success in an economically globalized context. There is a growing interest in leadership forms that focus more on sharing the responsibility of leadership between different individuals with different capabilities and qualities. One of these forms of leadership is shared leadership. In today's turbulent business environment, an organization's success is determined by its resilience through difficult times. Given that success has been linked to leadership, this systematic review aims to review the extant literature on the link between shared leadership and organizational resilience. The systematic review entailed searching relevant and reliable literature in various databases such as, Emerald, Google Scholar, APA PsycNet, Researchgate, and JSTOR using keywords (shared leadership, organization resilience, relationship, and impact of shared leadership on organizational resilience) primarily through Boolean operators. The initial search resulted in 200 articles, which were filtered using the study's inclusion and exclusion criteria resulting in 43 articles that were reviewed in this study. They culminated into a proposed integrated model appreciating the urgency of shared leadership in today's business environment. The review shows that the connection between shared leadership and organizational resilience has not received a lot of attention, making it a potential area for future studies.
\end{abstract}

Unlike in the past, where an individual who held the position of leadership individually took up the roles and functions of leadership, work teams have increasingly embraced the concept of distributing functional leadership roles among its members based on the requisite talent that each of the team members has (Goldsmith, 2010; Wang, Waldman, \& Zhang, 2014). 
Acknowledging this shift, research in the leadership field is also increasingly taking a new direction from one where leadership was a top-down vertical influence process to a direction of a horizontal as well as a shared leading process among members of a team (Lord et al., 2017). Transactional leadership, horizontal or collaborative leadership, classical management, transformational leadership, and ethical and critical leadership theories are the main viewpoints regarding leadership (Yukl, 2002). Shared leadership is an emerging concept in the leadership discourse. According to Carson et al. (2007), it is defined as a team phenomenon, which entails leadership roles and influence being distributed among team members.

Shared leadership has received attention from scholars and researchers in academic disciplines, including organizational behavior, industrial and organizational psychology, entrepreneurship, and strategic management are showing considerable interest. Shared leadership is different from other leadership forms of theories that have taken center stage in the past. As opposed to focusing on the eldership role of individual formal and appointed leaders, shared leadership focuses more on an agentic role that members in a team play in team leadership processes (Carson et al., 2007; Nicolaides et al., 2014). Research carried out on shared leadership has shown a possible influence and increased team effectiveness (e.g., Wang et al., 2014). As a result, shared leadership is an emerging field in eldership that is shifting how leadership has been understood (Cullen-Lester \& Yammarino, 2016).

There has also been a continued emphasis on the need for effective leadership characterized by shared vision construction, shared understandings, and building a professional learning culture through good communication (Gibbs, Press, \& Wong, 2019). Although many views exist about leadership, it is clear that the construct of leadership is not equivalent to a position or a person but a process of influencing and mobilizing people towards desired change. The desired organizational change is a blend of diverse attributes like values, attitudes, behaviors, approaches, and ideologies (Sinclair, 2014), moving away from Henri Fayol's general management theory that emphasizes planning and executing the control functions.

Globalization calls for adaptive leadership to deal with a continuously changing operating landscape. The leader's task involves supporting their constituents to face realities and responsibilities: Creating opportunities for upcoming leaders as problem-solvers to control the firm's strategic positioning. Notably, no meaningful change would occur without the correct scale of influence upon the subordinates. Collective problem-solving enables everyday resilience (Gilson et al., 2020).

Leadership is the art of influencing followers towards the achievement of organizational goals (Northouse, 2016), buying the hearts and minds of the employees to harvest organizational success. Notably, traditional leadership theory does not fully explain sustainability leadership (Bendell \& Little, 2015). The above calls for leadership hinging on learning and unlearning for people to become change agents operating at optimal levels and integrating sustainability into their leadership development programs, especially to manage disruptions. Recently, more scholars acknowledge that traditional forms of leadership do not work as well as they did in the past when it comes to fostering the achievement of organizational goals. O'Toole et al. (2002) stated that "Frequently, organizations learn the hard way that no one individual can save a company from mediocre performance - and no one individual, no matter how gifted a leader, can be 'right' all the time" (p. 67). Pearce (2007) said that “... we 
can no longer rely on simple notions of top-down, command-and-control leadership, based on the idea that workers are merely interchangeable drones" (p. 355).

Although there is growing research in shared leadership, most of the studies have paid attention to conceptual appreciation and theoretical anchorage, with few taking the empirical path. The few empirical studies on shared leadership have been skewed either as cross-sectional studies or have been conducted within a single organization. Others largely focus on a singular crisis, concentrate more in the health sector, are not inclusive in terms of gender, and fail to consider lower cadre staff. A majority of existing studies are also skewed towards the Asian and western countries thus limiting generalization to a great extent (e.g., Bergman et al., 2012; Hoch, 2013; Houghton et al., 2015; Muethel \& Hoegl, 2013).

The shared leadership formulations ride on the premise that individual leaders require their followers to be more effective in leading sustainable organizations. Disaster, natural or humanmade, can occur at any time wherever in the world. The likelihood of increased exposure to natural hazards, weather-related extremes, terrorism, and epidemics continues to grow as the world goes global, causing a high degree of uncertainty leads to disorientation, solid emotional disturbance, and loss of control amongst the leadership team and the employees (Gemma \& Aaron, 2020). For example, the Coronavirus pandemic has extraordinarily demanded top-notch leadership in business and beyond to manage fear amongst stakeholders and improve organizational learning. Therefore, organizational resilience is a crucial determinant of the success of any organization, and it is important to understand the role that leadership plays in organizational resilience.

Organizational resilience refers to the ability of an organization to identify, prepare for, and resolve disruptions and risks that jeopardize the organization with the least possible impact on life safety, reputation, and operations. Simply put, it is the ability to bounce back after disturbances or disruptive events and increase its capacity to adapt and handle such events in the future. Research on organizational resilience is relatively extensive, although its link to leadership, especially shared leadership is an area that still needs more research.

This systematic review focused on the construct of shared leadership and its role on organizational resilience in areas of:

1. How shared leadership and organizational resilience are appreciated and defined in the extant literature?

2. How are shared leadership, and organizational resilience operationalized and measured, and what are the notable strengths and weaknesses of employed research designs?

3. What is the future of shared leadership and organizational resilience research and possible model to apply?

The systematic review entailed identifying relevant literature pertinent to shared leadership and its interplay with organizational resilience. The selection criteria for the systematic review included:

i. Articles must have shared leadership as a primary variable

ii. The articles should look at organizational resilience and the role that shared leadership

iii. Must be in English

The search involved looking for relevant articles in various databases such as, Emerald, Google Scholar, APA PsycNet, Researchgate, and JSTOR. Additional material was also retrieved from the reference list of the article identified from the searches on the main databases. 


\section{Methodology}

The articles to be used had to be reliable, relevant to the topic under study, and have a high level of validity and generalisability. The main keywords used to search for the articles were shared leadership, organization resilience, relationship, and impact of shared leadership on organizational resilience. The keywords were broken down, and Boolean operators were used to gathering as many articles a possible. The words were (shared OR collaborative OR distributed AND (Resilience or Organizational resilience) AND (relationship or impact or influence). Boolean operators refer to simple words, namely AND, OR, NOT, or AND NOT; used conjunctions to either combine or exclude keywords when searching for articles in a given database. These operators help in getting search results that are more productive and focused. They also helped reduce the amount of time and effort that was spent eliminating inappropriate and unsuitable results. It is important to note that how you use the operators will determine whether you increase or reduce your search results (Alliant Libraries)

Using the Boolean Operators is different on every search database. Some require the operator to be typed in uppercase or accompanied by a specific punctuation mark. This is usually indicated on the guidelines of using a given database. The operators work as follows.

i. AND - when you use and, both terms/ keywords you have indicated have to be available for an article to be included in the results list. If any of the terms are missing, the article is excluded. This narrows down your search.

ii. OR - these included results with either term (or both) broadening your search.

iii. NOT or AND NOT- depending on the coding of the database being used, the first term is searched. Any articles containing the terms after the operator are removed from the record or results list.

Using the Boolean operators and keywords, a total of 200 articles were produced. To narrow down this search, several filters and limiters were applied. The first one was the publication date. Any article published outside the 2006 to 2021 publication date bracket was removed, leaving 189 articles. The next filter was the articles dealing with leadership and resilience. With this filter, the article was narrowed down to 100. The next filter was the connection of shared leadership to organizational resilience, which resulted in 43 articles that have been used for this critical narrative literature review. Figure 1 displays the inclusion and exclusion procedures.

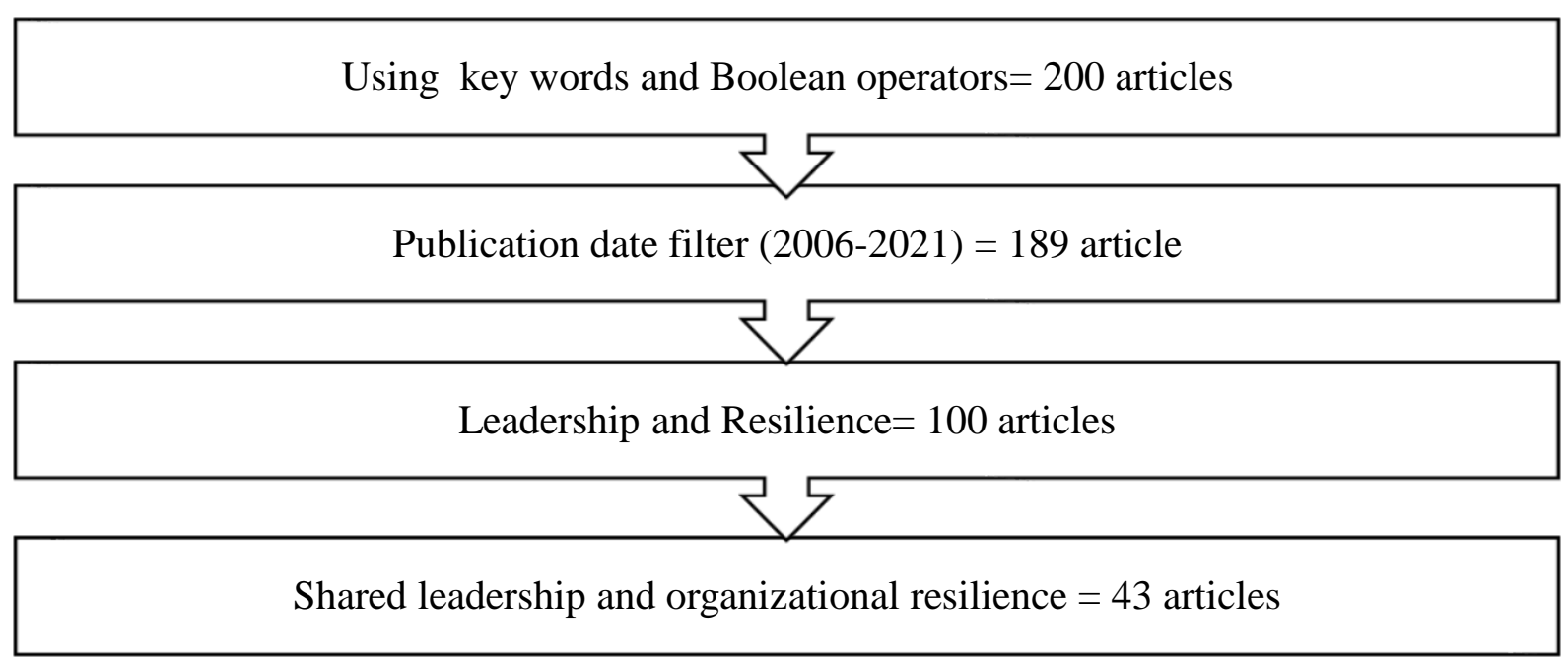

Figure 1. Inclusion and exclusion procedure 
The strength of this search is that different parameters were used to ensure that the articles selected were relevant and reliable. The search was also carried out in different databases.

\section{Analysis}

The systematic review analysis entailed a three-phased approach that looked at the 43 main articles, with the primary variables being Shared leadership and organizational resilience. The first phase evaluated the extant conceptualization of the construct of shared leadership mainly by its operationalization (e.g., Carson et al., 2007; Wang et al., 2014 ;), and its key dimensions (e.g., Yukl, 2002), and forms (e.g., Wang et al., 2014). The conceptual evaluation of organizational resilience focused on the construct both as a process with measurable outcomes (e.g., Gilstrap et al., 2016; Wenger, 2017) and a position that supports long-term sustainability. An exciting aspect is how different resilience theorists advance arguments regarding opposing elements concerning resilience: The construct of bouncing back (Wenger, 2017). Therefore, the conceptual review summarizes the available background on the variables under study identifying, the meaning and relevance to organizational transformation and potential benefits that would flow from their review.

The conceptual interlude ushers the entry of the second phase on theoretical evaluation, which summarizes the influence of Transactional leadership theory, complexity theory, behavioral theory, transactional theory, and multi-stakeholder theory on the application of shared leadership in meeting society's broader expectations. Sustainability management is seen as a crucial focus in organizational agency relationships. The empirical literature reviews past empirical studies mainly in the Health sector, community projects, non-governmental organizations, and other organizations, most of them from outside the African continent where only a few studies existed. The above opened up a horizon of existing gaps and opportunities for future research, noting that there are limited studies about the interplay of shared leadership, and organizational resilience globally (Sandesh \& Sharma, 2020).

The final phase utilized the various relationships from the empirical and theoretical evaluation to inform a new theoretical model to guide future studies regarding the construct of shared leadership and organizational resilience, proposing the need for shared leadership to generate organizations with superior adjustment, absorptive and transformative capacities. Table 1 shows the results of the article search. The results are presented based on authors" name, area of focus, methodology, results, and limitations. 


\section{Results and Discussion}

Table 1

The Results of the Article Search

\begin{tabular}{|c|c|c|c|c|c|}
\hline & Article & Area of Focus & Methodology & Results & Limitations \\
\hline 1. & $\begin{array}{l}\text { Bendell \& } \\
\text { Little }(2015)\end{array}$ & $\begin{array}{l}\text { Sustainability } \\
\text { leadership }\end{array}$ & $\begin{array}{l}\text { Literature } \\
\text { review }\end{array}$ & $\begin{array}{l}\text { - Traditional leadership theories are highly } \\
\text { problematic when it comes to the pursuit of } \\
\text { sustainable leadership } \\
\text { - There is a lack of common frameworks, } \\
\text { methods, and metrics on sustainability } \\
\text { leadership } \\
\text { - Unlearning leadership as is currently } \\
\text { assumed and taught is the first step to } \\
\text { developing sustainable leadership }\end{array}$ & - Not indicated \\
\hline 2. & $\begin{array}{l}\text { Bergman et } \\
\text { al. }(2012)\end{array}$ & $\begin{array}{l}\text { Shared leadership } \\
\text { and decision- } \\
\text { making }\end{array}$ & $\begin{array}{l}\text { Cross- } \\
\text { sectional } \\
\text { design }\end{array}$ & $\begin{array}{l}\text { - Teams with shared leadership reported } \\
\text { fewer conflicts, there was greater } \\
\text { consensus, and intra-group trust and } \\
\text { cohesion was higher in teams with shared } \\
\text { leadership in comparison to those without } \\
\text { shared leadership } \\
\text { - Shared leadership positively contributes to } \\
\text { the overall functioning of a team. }\end{array}$ & $\begin{array}{l}\text { - Only focused on short-term } \\
\text { project teams } \\
\text { - Only one type of leadership } \\
\text { focused on } \\
\text { - Controlled environment for } \\
\text { participants } \\
\text { - Use of ad-hoc groups } \\
\text { - Robustness might need } \\
\text { research on larger groups of } \\
\text { participants } \\
\text { - Cross-sectional design } \\
\text { limiting causal inferences }\end{array}$ \\
\hline 3. & $\begin{array}{l}\text { Bolden et al. } \\
(2015)\end{array}$ & $\begin{array}{l}\text { Shared leadership } \\
\text { in Australia and } \\
\text { UK }\end{array}$ & $\begin{array}{l}\text { Qualitative } \\
\text { survey }\end{array}$ & $\begin{array}{l}\text { - Shared leadership is not just a desirable } \\
\text { leadership approach but rather a necessity } \\
\text { in higher education institutions } \\
\text { - Shared leadership requires a systematic } \\
\text { approach focusing on the relationship } \\
\text { between individuals, organizations, and } \\
\text { groups. }\end{array}$ & $\begin{array}{l}\text { - Focused on higher education } \\
\text { institutions only }\end{array}$ \\
\hline 4. & $\begin{array}{l}\text { Carson, } \\
\text { Tesluk, \& } \\
\text { Marrone } \\
(2007)\end{array}$ & $\begin{array}{l}\text { Antecedent } \\
\text { conditions that } \\
\text { lead to shared } \\
\text { leadership and } \\
\text { the influence of } \\
\text { shared leadership } \\
\text { on team } \\
\text { performance }\end{array}$ & $\begin{array}{l}\text { Partial cross- } \\
\text { sectional study }\end{array}$ & $\begin{array}{l}\text { - The internal team environment, which } \\
\text { entails shared purpose and social support, } \\
\text { and external coaching, are important } \\
\text { predictors of shared leadership } \\
\text { - Shared leadership predicts team } \\
\text { performance } \\
\text { - In teams that lack an internal team } \\
\text { environment, external coaching is vital in } \\
\text { the development of shared leadership and } \\
\text { eventually improving team performance. }\end{array}$ & $\begin{array}{l}\text { - Testing of causality was not } \\
\text { possible due to the use of a } \\
\text { partially cross-sectional } \\
\text { design } \\
\text { - The participants were only } \\
\text { students and non-full-time } \\
\text { employees, leaving out the } \\
\text { full-time employees } \\
\text { - Common source bias. }\end{array}$ \\
\hline 5. & $\begin{array}{l}\text { Cobanoglu } \\
(2020)\end{array}$ & $\begin{array}{l}\text { The connection } \\
\text { between shared } \\
\text { leadership and } \\
\text { organizational } \\
\text { commitment in } \\
\text { primary and } \\
\text { secondary } \\
\text { schools }\end{array}$ & $\begin{array}{l}\text { Relational } \\
\text { survey }\end{array}$ & $\begin{array}{l}\text { Shared leadership positively and } \\
\text { significantly predicts organizational } \\
\text { commitment in primary and secondary } \\
\text { schools }\end{array}$ & $\begin{array}{l}\text { - The research was carried out } \\
\text { in primary and secondary } \\
\text { school only, meaning that } \\
\text { the study did not cover all } \\
\text { educational organizations. } \\
\text { - The schools the study was } \\
\text { carried in were all in the } \\
\text { central districts of the } \\
\text { metropolitan city. This } \\
\text { means that there might be } \\
\text { different results in schools in } \\
\text { the countryside }\end{array}$ \\
\hline 6. & $\begin{array}{l}\text { Cullen- } \\
\text { Lester \& \& } \\
\text { Yammarino } \\
(2016)\end{array}$ & $\begin{array}{lr}\text { Research } & \text { and } \\
\text { practice } & \text { on } \\
\text { collective } & \text { and } \\
\text { network } & \\
\text { approaches } & \text { to } \\
\text { leadership } & \end{array}$ & $\begin{array}{l}\text { Literature } \\
\text { review }\end{array}$ & $\begin{array}{l}\text { - Formal leadership roles and structure play } \\
\text { important roles in the success of } \\
\text { organizations } \\
\text { - There is growing interest and emergence of } \\
\text { collective and network approaches to } \\
\text { leadership in many organizations }\end{array}$ & $\begin{array}{l}\text { - Only nine studies were } \\
\text { reviewed, which is a small } \\
\text { size }\end{array}$ \\
\hline
\end{tabular}




\begin{tabular}{|c|c|c|c|c|c|}
\hline 7. & $\begin{array}{l}\text { DeRue, } \\
\text { Nahrgang, \& } \\
\text { Ashford } \\
(2015)\end{array}$ & $\begin{array}{l}\text { Interpersonal } \\
\text { perceptions and } \\
\text { leadership } \\
\text { structures in } \\
\text { groups }\end{array}$ & $\begin{array}{l}\text { Two-wave } \\
\text { design }\end{array}$ & $\begin{array}{l}\text { - The emergent natures of leadership } \\
\text { structures in self-managing teams and } \\
\text { foreground interpersonal perspectives lead } \\
\text { to varying informal and emergent } \\
\text { leadership structures }\end{array}$ & $\begin{array}{l}\text { - Ad hoc team working } \\
\text { together for seven weeks } \\
\text { where the study sample } \\
\text { making generalizability of } \\
\text { results difficult } \\
\text { - Speed of leadership } \\
\text { emergence cannot be } \\
\text { assessed } \\
\text { - Data was collected midpoint } \\
\text { of the teams' operation, } \\
\text { meaning that modeling what } \\
\text { happened from the start was } \\
\text { impossible } \\
\text { - The groups studied were not } \\
\text { significantly contextualized }\end{array}$ \\
\hline 8. & $\begin{array}{l}\text { Devos, } \\
\text { Tuytens, \& } \\
\text { Hulpia } \\
\text { (2014) }\end{array}$ & $\begin{array}{l}\text { Relationship } \\
\text { between } \\
\text { leadership and } \\
\text { organizational } \\
\text { commitment }\end{array}$ & $\begin{array}{l}\text { Cross- } \\
\text { sectional study }\end{array}$ & $\begin{array}{l}\text { - The principal's leadership in the studied } \\
\text { schools affected the organizational } \\
\text { commitment of teachers. } \\
\text { - Cooperation at the top level of leadership } \\
\text { and participative decision making was } \\
\text { directly related to organizational } \\
\text { commitment }\end{array}$ & $\begin{array}{l}\text { - Same source bias due to use } \\
\text { of self-reported } \\
\text { questionnaires } \\
\text { - The teachers' organizational } \\
\text { commitment was used as a } \\
\text { dependent variable } \\
\text { - The cross-sectional design } \\
\text { does not allow for } \\
\text { conclusions on causality } \\
\text { among variables. }\end{array}$ \\
\hline 9. & $\begin{array}{l}\text { Doffer et al. } \\
(2020)\end{array}$ & $\begin{array}{l}\text { Post- Corona } \\
\text { Leadership }\end{array}$ & Essay & $\begin{array}{l}\text { - Collaborative leadership is vital in the face } \\
\text { of global challenges like the Coronavirus. } \\
\text { - Individual leadership skills influence how } \\
\text { a leader will deal with a global challenge } \\
\text { and their perception towards collaborating } \\
\text { with other leaders in the global space }\end{array}$ & $\begin{array}{l}\text { - Limited predictive value of } \\
\text { the frameworks used in the } \\
\text { essay. }\end{array}$ \\
\hline 10. & $\begin{array}{l}\text { Erkutlu } \\
\text { (2012) }\end{array}$ & $\begin{array}{l}\text { Relationship } \\
\text { between shared } \\
\text { leadership and } \\
\text { team proactive } \\
\text { behavior with } \\
\text { organizational } \\
\text { culture as the } \\
\text { mediating } \\
\text { variable }\end{array}$ & $\begin{array}{l}\text { Quantitative } \\
\text { study }\end{array}$ & $\begin{array}{l}\text { - Shared leadership within work teams was } \\
\text { positively related to proactive behavior in } \\
\text { the team. The team proactive behavior was } \\
\text { higher in organizations that had supportive } \\
\text { cultures. }\end{array}$ & $\begin{array}{l}\text { - Generalizability was } \\
\text { difficult because the } \\
\text { demographics were not } \\
\text { wholly representative of the } \\
\text { population. The majority of } \\
\text { participants were male, } \\
\text { young in terms of age, and } \\
\text { has a job tenure of fewer } \\
\text { than seven years. }\end{array}$ \\
\hline 11. & $\begin{array}{l}\text { Faulkner, } \\
\text { Brown, \& } \\
\text { Quinn (2018) }\end{array}$ & $\begin{array}{l}\text { Community } \\
\text { resilience }\end{array}$ & $\begin{array}{l}\text { Mixed } \\
\text { methods - } \\
\text { survey and } \\
\text { focus group } \\
\text { discussions }\end{array}$ & $\begin{array}{l}\text { - Community resilience is enabled by five } \\
\text { main capabilities among community } \\
\text { members. They are leadership, place } \\
\text { attachment, community networks, } \\
\text { community cohesion and efficacy, and } \\
\text { knowledge and learning. } \\
\text { - There is no universal mechanism for } \\
\text { enabling community resilience. Each } \\
\text { community is different and therefore poses } \\
\text { different capabilities. }\end{array}$ & - Not indicated \\
\hline 12. & $\begin{array}{l}\text { Fernandez \& } \\
\text { Tima (2011) }\end{array}$ & $\begin{array}{l}\text { Employee } \\
\text { empowerment } \\
\text { and performance } \\
\text { improvement }\end{array}$ & $\begin{array}{l}\text { Empirical } \\
\text { study }\end{array}$ & $\begin{array}{l}\text { - Empowerment practices like providing } \\
\text { employees with job-related knowledge and } \\
\text { skills have a positive and significant impact } \\
\text { on perceived performance }\end{array}$ & $\begin{array}{l}\text { - The study only focused on } \\
\text { federal agencies } \\
\text { - Results could be susceptible } \\
\text { to common source bias } \\
\text { because data was self- } \\
\text { reported and gathered } \\
\text { through a single survey. }\end{array}$ \\
\hline 13. & $\begin{array}{l}\text { Gilstrap et al. } \\
\text { (2016) }\end{array}$ & $\begin{array}{l}\text { Leadership in } \\
\text { organizational } \\
\text { crises }\end{array}$ & $\begin{array}{l}\text { In-depth } \\
\text { interviews }\end{array}$ & $\begin{array}{l}\text { - The characteristic of effective crisis } \\
\text { leadership includes the leader being a team } \\
\text { player, strategic, transparent, quick in } \\
\text { responding, self-composed and prepared. } \\
\text { - Diagnostic and prognostic sense giving } \\
\text { activities were more clearly observed than } \\
\text { motivational sense giving activities across }\end{array}$ & $\begin{array}{l}\text { - The sampling method did } \\
\text { not consider organizations } \\
\text { with human-generated crises } \\
\text { - The study only detected } \\
\text { latent motivational factors } \\
\text { among the crises leaders }\end{array}$ \\
\hline
\end{tabular}




\begin{tabular}{|c|c|c|c|c|c|}
\hline & & & & $\begin{array}{l}\text { crises leaders in the nonprofit } \\
\text { organizations }\end{array}$ & $\begin{array}{l}\text { - The longitudinal approach to } \\
\text { crisis leadership and } \\
\text { evaluation of the lifecycle of } \\
\text { organization crises was not } \\
\text { considered. }\end{array}$ \\
\hline 14. & $\begin{array}{l}\text { Gittell et al. } \\
(2006)\end{array}$ & $\begin{array}{l}\text { Importance of } \\
\text { financial and } \\
\text { social capital on } \\
\text { organizational } \\
\text { resilience }\end{array}$ & Case study & $\begin{array}{l}\text { - Layoffs have been used as the first } \\
\text { response to dealing with a crisis that causes } \\
\text { a drop in demand. However, high } \\
\text { performance required in such times } \\
\text { required commitment and loyalty to the } \\
\text { organization, which is impossible with } \\
\text { layoffs. }\end{array}$ & $\begin{array}{l}\text { - Only focused on a single } \\
\text { event (September } 11 \\
\text { terrorist attack) and impact } \\
\text { on one industry (airlines) }\end{array}$ \\
\hline 15. & $\begin{array}{l}\text { Goksoy } \\
(2016)\end{array}$ & $\begin{array}{l}\text { Relationship } \\
\text { between shared } \\
\text { leadership and } \\
\text { distributed } \\
\text { leadership }\end{array}$ & $\begin{array}{l}\text { Relational } \\
\text { survey and } \\
\text { casual design }\end{array}$ & $\begin{array}{l}\text {-The relationship between the shared } \\
\text { leadership scale and distributed leadership } \\
\text { scale is a positive, medium level, and } \\
\text { significant one. } \\
\text {-The term 'collective leadership should be } \\
\text { used to bridge the gap between shared } \\
\text { leadership and distributed leadership - two } \\
\text { leadership approaches are often used } \\
\text { interchangeably and prevent cognitive } \\
\text { complexity. }\end{array}$ & - Not indicated \\
\hline 16. & Grote (2019) & $\begin{array}{l}\text { Relationship } \\
\text { between } \\
\text { leadership and } \\
\text { organizational } \\
\text { resilience }\end{array}$ & $\begin{array}{l}\text { Literature } \\
\text { review }\end{array}$ & $\begin{array}{l}\text { - Three fundamental leadership } \\
\text { requirements for organizational resilience } \\
\text { were identified. They are the leaders' } \\
\text { ability to be adaptive, design } \\
\text { organizational mechanisms that support } \\
\text { individual and team adaptivity, and the } \\
\text { leaders' role in establishing organizational } \\
\text { cultures. }\end{array}$ & $\begin{array}{l}\text { - A brief literature review } \\
\text { meaning it might not be a } \\
\text { reliable representation of } \\
\text { extant literature in this field } \\
\text { of study. }\end{array}$ \\
\hline 17. & $\begin{array}{l}\text { Hoch, \& } \\
\text { Dulebohn } \\
(2017)\end{array}$ & $\begin{array}{l}\text { Shared leadership } \\
\text { in virtual teams }\end{array}$ & $\begin{array}{l}\text { Literature } \\
\text { review }\end{array}$ & $\begin{array}{l}\text { - The inputs in shared leadership in virtual } \\
\text { teams included organizational factors such } \\
\text { as team design, reward systems, } \\
\text { communication, and training; team } \\
\text { leadership and team composition } \\
\text { - Cognitive, affective, motivational, and } \\
\text { behavioral team processes and emergent } \\
\text { states were the moderating factors and the } \\
\text { outcomes included performance and } \\
\text { effectiveness at the individual and } \\
\text { organizational level. }\end{array}$ & $\begin{array}{l}\text { - Propositions based on } \\
\text { individual recommendation } \\
\text { and not on research }\end{array}$ \\
\hline 18. & Hoch (2013) & $\begin{array}{l}\text { Relationship } \\
\text { between shared } \\
\text { leadership and } \\
\text { innovative } \\
\text { behavior }\end{array}$ & $\begin{array}{l}\text { Cross- } \\
\text { sectional study }\end{array}$ & $\begin{array}{l}\text { - Shared and vertical leadership (not team } \\
\text { composition) was positively related to the } \\
\text { team's innovative behavior. } \\
\text { - Vertical transformational and empowering } \\
\text { leadership and team composition in terms } \\
\text { of integrity were positively related to } \\
\text { shared leadership }\end{array}$ & $\begin{array}{l}\text { - Being a cross-sectional } \\
\text { study, it precluded causality } \\
\text { - The sample was } \\
\text { predominately male } \\
\text { - A broad measure of } \\
\text { leadership } \\
\text { - No focus on shared mental } \\
\text { models }\end{array}$ \\
\hline 19. & $\begin{array}{l}\text { Houghton et } \\
\text { al. (2015) }\end{array}$ & Shared leadership & $\begin{array}{l}\text { Literature } \\
\text { review }\end{array}$ & & $\begin{array}{l}\text { - no statistics on the data } \\
\text { reviewed }\end{array}$ \\
\hline 20. & Jarad (2012) & $\begin{array}{l}\text { Leadership } \\
\text { characteristics } \\
\text { and project } \\
\text { success in the } \\
\text { construction } \\
\text { industry in the } \\
\text { Gaza Strip }\end{array}$ & $\begin{array}{l}\text { Comparative } \\
\text { study } \\
-\quad \text { interviews } \\
\text { and a case } \\
\text { study }\end{array}$ & $\begin{array}{l}\text { - There is a strong relationship between the } \\
\text { leadership characteristics of a project } \\
\text { manager and the success/failure of the } \\
\text { project } \\
\text { - The leading characteristics associated with } \\
\text { project success include monitoring, } \\
\text { problem-solving, informed judgment, team } \\
\text { building, initiative, influencing, } \\
\text { communication, vision, planning and goal } \\
\text { setting, time management, discipline, } \\
\text { ethics, conflict resolution, positive } \\
\text { expectations, and empowerment. } \\
\text { - The important methods to develop the } \\
\text { above skills are through job experience, }\end{array}$ & - Not indicated \\
\hline
\end{tabular}




\begin{tabular}{|c|c|c|c|c|c|}
\hline & & & & $\begin{array}{l}\text { watching, observing, mentorship and } \\
\text { coaching from seniors, company training, } \\
\text { educational courses, and self-education }\end{array}$ & \\
\hline 21. & Magis (2010) & $\begin{array}{l}\text { Community } \\
\text { resilience }\end{array}$ & $\begin{array}{l}\text { Literature } \\
\text { review }\end{array}$ & $\begin{array}{l}\text { - Resilience is the ability of a system to } \\
\text { sustain itself through adaptations and } \\
\text { occasional transformation } \\
\text { - In addition to the definition, this study also } \\
\text { gave the eight dimensions of community } \\
\text { resilience which are community resources, } \\
\text { active agents, strategic action, collective } \\
\text { actions, equity, impact, resource } \\
\text { engagement, and resource development }\end{array}$ & - Not indicated \\
\hline 22. & $\begin{array}{l}\text { Langeland et } \\
\text { al. (2016) }\end{array}$ & $\begin{array}{l}\text { How to increase } \\
\text { organizational } \\
\text { resilience }\end{array}$ & $\begin{array}{l}\text { Literature } \\
\text { review }\end{array}$ & $\begin{array}{l}\text { - Resilience was defined as the attribute of as } \\
\text { a system that indicated its ability to } \\
\text { maintain critical operations in the face of } \\
\text { adverse disruptions } \\
\text { - Information sharing and shared awareness } \\
\text { of mission increases effectiveness and } \\
\text { efficiency of operations during and after } \\
\text { threat events } \\
\text { - Clear error reporting structures and } \\
\text { cultures allow the development of } \\
\text { resilience perenthel with } \\
\text { - Balancing between flexible personnel } \\
\text { distributed decision making and } \\
\text { specialized personnel with centralized } \\
\text { decision making is vital to resilience } \\
\text { - Training on specific and general threat } \\
\text { response procedures improves resilience }\end{array}$ & - Not indicated \\
\hline 23. & $\begin{array}{l}\text { Liang \& Gu } \\
(2016)\end{array}$ & $\begin{array}{l}\text { Shared leadership } \\
\text { and creativity }\end{array}$ & $\begin{array}{l}\text { Comparative } \\
\text { study }\end{array}$ & $\begin{array}{l}\text { - The study was drawn on social cognitive } \\
\text { theory. Shared leadership has a positive } \\
\text { impact on creativity. } \\
\text { - Shared leadership motivated team potency } \\
\text { and improved individual competence and } \\
\text { creativity }\end{array}$ & $\begin{array}{l}\text { - Carried out in a specific area } \\
\text { in China, making } \\
\text { generalizability difficult }\end{array}$ \\
\hline 24. & $\begin{array}{l}\text { Liphadzi, } \\
\text { Aigbavboa, } \\
\text { \& Thwala } \\
(2017)\end{array}$ & $\begin{array}{l}\text { Difference } \\
\text { between } \\
\text { leadership and } \\
\text { management }\end{array}$ & $\begin{array}{l}\text { Literature } \\
\text { review }\end{array}$ & $\begin{array}{l}\text { Leadership and management are two district } \\
\text { concepts. Leadership includes social } \\
\text { influence and the leader's role in setting a } \\
\text { vision or purpose of change for an } \\
\text { organization. Management, on the other } \\
\text { hand, is associated with the fulfillment of } \\
\text { the goals and processes of an organization }\end{array}$ & - Not indicated \\
\hline 25. & $\begin{array}{l}\text { Locke, } \\
\text { Srivastava, \& } \\
\text { Bartol (2006) }\end{array}$ & $\begin{array}{l}\text { Role of } \\
\text { knowledge } \\
\text { sharing and team } \\
\text { efficacy in the } \\
\text { relationship } \\
\text { between } \\
\text { empowering } \\
\text { leadership and } \\
\text { team } \\
\text { performance }\end{array}$ & Survey & $\begin{array}{l}\text { - Empowering leadership is positively } \\
\text { related to both team efficacy and } \\
\text { knowledge sharing. } \\
\text { - Knowledge sharing and team efficacy are } \\
\text { positively related to improved performance }\end{array}$ & $\begin{array}{l}\text { - No causal design } \\
\text { - Applicability to other types } \\
\text { of business or operations in } \\
\text { limited } \\
\text { - Same data source leading to } \\
\text { common method bias } \\
\text { - The degree of non-responses } \\
\text { could not be ascertained } \\
\text { since the number of } \\
\text { managers in each team was } \\
\text { not recorded. }\end{array}$ \\
\hline 26. & $\begin{array}{l}\text { Marques } \\
\text { (2013) }\end{array}$ & $\begin{array}{l}\text { Soft skills as an } \\
\text { intrinsic part of } \\
\text { successful } \\
\text { leadership }\end{array}$ & & $\begin{array}{l}\text { - Soft skills are vital in the success of a } \\
\text { leader }\end{array}$ & $\begin{array}{l}\text { - Small sample size } \\
\text { - The study was carried out in } \\
\text { the Los Angeles area, which } \\
\text { is metropolitan. Therefore, } \\
\text { data from other areas with } \\
\text { different economic and } \\
\text { cultural prerequisites may be } \\
\text { different. }\end{array}$ \\
\hline 27. & $\begin{array}{l}\text { Morgeson, } \\
\text { DeRue, \& }\end{array}$ & $\begin{array}{l}\text { Team leadership } \\
\text { structures and } \\
\text { processes }\end{array}$ & $\begin{array}{l}\text { Literature } \\
\text { review }\end{array}$ & $\begin{array}{l}\text { - There are four sources of team leadership } \\
\text { internal formal, internal informal, external } \\
\text { formal, and informal external sources. }\end{array}$ & - Not indicated \\
\hline
\end{tabular}




\begin{tabular}{|c|c|c|c|c|c|}
\hline & $\begin{array}{l}\text { Karam } \\
(2010)\end{array}$ & & & $\begin{array}{l}\text { - There are } 15 \text { main functions of team } \\
\text { leadership and are divided into two phases; } \\
\text { - the transition phase and the action phase } \\
\text { - Transition phase - compose team, define } \\
\text { the mission, establish expectations and } \\
\text { goals, structure and plan, train and develop } \\
\text { team, sense-making, and provide feedback. } \\
\text { - Action phase - monitor team, manage team } \\
\text { boundaries, challenge team, perform team } \\
\text { tasks, solve problems, provide resources, } \\
\text { encourage self-management and support } \\
\text { social cultures }\end{array}$ & \\
\hline 28. & $\begin{array}{l}\text { Muethel \& } \\
\text { Hoegl (2013) }\end{array}$ & $\begin{array}{l}\text { Effectiveness of } \\
\text { shared leadership }\end{array}$ & $\begin{array}{l}\text { Literature } \\
\text { review }\end{array}$ & $\begin{array}{l}\text { - The assumption of the existing theory that } \\
\text { team members are always open to } \\
\text { influence from fellow team members is } \\
\text { disregarded } \\
\text { - Independent professionals consciously } \\
\text { decide whether or not to adhere to } \\
\text { influence from fellow team members } \\
\text { - To understand shared leadership, it is } \\
\text { important to take into account the } \\
\text { importance of a leader, a follower, and a } \\
\text { relationship perspective. }\end{array}$ & $\begin{array}{l}\text { No statistics on the reviewed } \\
\text { literature }\end{array}$ \\
\hline 29. & $\begin{array}{l}\text { Muthimi \& } \\
\text { Kilika (2018) }\end{array}$ & $\begin{array}{l}\text { Leadership, } \\
\text { behavioral focus, } \\
\text { and performance }\end{array}$ & $\begin{array}{l}\text { Literature } \\
\text { review }\end{array}$ & $\begin{array}{l}\text { - Leadership strategy affects a firm's } \\
\text { strategic behavior focus } \\
\text { - The construct in the study was based on } \\
\text { theoretical frameworks drawn from the } \\
\text { LMX theory, contingency theory, } \\
\text { transformational leadership theory, and } \\
\text { leadership strategy model. }\end{array}$ & $\begin{array}{l}\text { - There was no presentation of } \\
\text { the relationship between } \\
\text { leadership, behavior focus, } \\
\text { and performance. }\end{array}$ \\
\hline 30. & $\begin{array}{l}\text { Nathaniel, } \\
\text { Carlos, \& } \\
\text { Jesse (2019) }\end{array}$ & $\begin{array}{l}\text { Pros and cons of } \\
\text { shared leadership }\end{array}$ & $\begin{array}{l}\text { Descriptive } \\
\text { qualitative } \\
\text { study }\end{array}$ & $\begin{array}{l}\text { - The benefits of shared leadership that were } \\
\text { identified included enhanced decision } \\
\text { making, exceptional outcomes, ease in } \\
\text { problem-solving, team-member fit, } \\
\text { creative innovation, team synergy, } \\
\text { individual well-being, sustained growth, } \\
\text { healthy organizational culture, and } \\
\text { organizational vitality. } \\
\text { - The drawbacks included the difficulty of } \\
\text { the shared leadership model, potential lack } \\
\text { of follow-through, the danger of immature } \\
\text { or usurping team members, lack of } \\
\text { acceptance of the model, and lack of } \\
\text { efficiency }\end{array}$ & $\begin{array}{l}\text { - Only leaders from shared } \\
\text { leadership teams that were } \\
\text { committed to the model and } \\
\text { experiencing success were } \\
\text { interviewed, leading to } \\
\text { biased findings }\end{array}$ \\
\hline 31. & $\begin{array}{l}\text { Nicolaides et } \\
\text { al. (2014) }\end{array}$ & $\begin{array}{l}\text { Relationship } \\
\text { between shared } \\
\text { leadership and } \\
\text { team } \\
\text { performance, as } \\
\text { well as the role } \\
\text { that team } \\
\text { confidence plays } \\
\text { in the above } \\
\text { relationship }\end{array}$ & Meta-analysis & $\begin{array}{l}\text { - Shared leadership has a significant } \\
\text { influence on performance } \\
\text { - Shared leadership is effective when the } \\
\text { interdependence in a team and team } \\
\text { confidence is high } \\
\text { - The team size or tenure does not affect the } \\
\text { impact of shared leadership on } \\
\text { performance. }\end{array}$ & $\begin{array}{l}\text { - None of the studies includes } \\
\text { in the meta-analysis used a } \\
\text { true experimental design. } \\
\text { - A relatively small sample } \\
\text { size of the primary studies } \\
\text { included in the Meta- } \\
\text { analysis. } \\
\text { - Inability to account for the } \\
\text { dynamic nature of team } \\
\text { tenure. }\end{array}$ \\
\hline 32. & $\begin{array}{l}\text { Parris \& } \\
\text { Peachey } \\
(2013)\end{array}$ & $\begin{array}{l}\text { Servant } \\
\text { leadership }\end{array}$ & $\begin{array}{l}\text { Systematic } \\
\text { review }\end{array}$ & $\begin{array}{l}\text { - There was no consensus on the definition } \\
\text { on servant definition } \\
\text { - Servant leadership is being investigated in } \\
\text { various contexts, themes, and cultures } \\
\text { - Multiple measures are being used to } \\
\text { explore servant leadership } \\
\text { - Servant leadership is a viable leadership } \\
\text { theory and helps organizations improve the } \\
\text { well-being of followers. }\end{array}$ & $\begin{array}{l}\text { - The systematic review only } \\
\text { reviewed indexed journals } \\
\text { available in the researcher's } \\
\text { university library. Articles } \\
\text { that were not peer-reviewed } \\
\text { or indexed were not } \\
\text { reviewed. } \\
\text { - The only article in English } \\
\text { were reviewed } \\
\text { - The ability to explore all } \\
\text { methodological }\end{array}$ \\
\hline
\end{tabular}




\begin{tabular}{|c|c|c|c|c|c|}
\hline & & & & & $\begin{array}{l}\text { considerations was limited } \\
\text { by the study's integration of } \\
\text { results conducted using both } \\
\text { qualitative and quantitative } \\
\text { data analysis methods }\end{array}$ \\
\hline 33. & $\begin{array}{l}\text { Paul, } \text { Bamel, } \\
\& \quad \text { Garg } \\
\begin{array}{ll}(2016) & \end{array}\end{array}$ & $\begin{array}{l}\text { Employee } \\
\text { resilience and } \\
\text { organizational } \\
\text { citizenship } \\
\text { behavior (OCB) } \\
\text { with } \\
\text { organizational } \\
\text { commitment as } \\
\text { the mediating } \\
\text { variable }\end{array}$ & $\begin{array}{l}\text { Cross- } \\
\text { sectional study } \\
\text { design }\end{array}$ & $\begin{array}{l}\text { - There is a positive relationship between } \\
\text { resilience and organizational citizenship } \\
\text { behavior } \\
\text { - Resilience influences organizational } \\
\text { commitment. } \\
\text { - Resilience directly influences OCB and } \\
\text { also influences it indirectly through } \\
\text { organizational commitment }\end{array}$ & $\begin{array}{l}\text { - The study purely relied on } \\
\text { cross-sectional data. } \\
\text { - A majority of the } \\
\text { respondents were male, } \\
\text { making generalizability } \\
\text { difficult } \\
\text { - Causation among the } \\
\text { variable was not examined. }\end{array}$ \\
\hline 34. & $\begin{array}{l}\text { Pearce, } \\
\text { Wassenaar, } \\
\& \quad \text { Manz } \\
(2014)\end{array}$ & $\begin{array}{l}\text { Responsible } \\
\text { leadership and } \\
\text { how shared } \\
\text { leadership } \\
\text { processes support } \\
\text { it }\end{array}$ & $\begin{array}{l}\text { Ethnographic } \\
\text { study }\end{array}$ & $\begin{array}{l}\text { - Shared leadership is vital in developing } \\
\text { responsible leadership and can therefore be } \\
\text { used to solve issues of irresponsible } \\
\text { leadership }\end{array}$ & - Not indicated \\
\hline 35. & $\begin{array}{l}\text { Scott-Young, } \\
\text { Georgy, \& } \\
\text { Grisinger } \\
(2019)\end{array}$ & Shared leadership & $\begin{array}{l}\text { Systematic } \\
\text { literature } \\
\text { review }\end{array}$ & $\begin{array}{l}\text { - Shared leadership is a construct that adds } \\
\text { value to the project management construct } \\
\text { - Shared leadership has the potential to } \\
\text { enhance team functioning and project } \\
\text { performance } \\
\text { - Development of a multi-level moderated I- } \\
\text { M-O-I model based on systems theory. }\end{array}$ & - Not indicated \\
\hline 36. & $\begin{array}{l}\text { Sharma \& } \\
\text { Sharma } \\
(2020)\end{array}$ & $\begin{array}{l}\text { Links between } \\
\text { team resilience, } \\
\text { competitive } \\
\text { advantage, and } \\
\text { organizational } \\
\text { effectiveness }\end{array}$ & $\begin{array}{l}\text { Cross- } \\
\text { sectional } \\
\text { design }\end{array}$ & $\begin{array}{l}\text { - There is a significant relationship between } \\
\text { team resilience and organizational } \\
\text { effectiveness. } \\
\text { - Competitive advantage was a partial } \\
\text { mediator among the relationship between } \\
\text { team resilience and organizational } \\
\text { effectiveness } \\
\text { - }\end{array}$ & $\begin{array}{l}\text { - Conclusion on causality is } \\
\text { difficult to make due to the } \\
\text { cross-sectional design used }\end{array}$ \\
\hline 37. & $\begin{array}{l}\text { Simons \& } \\
\text { Buitendach } \\
\text { (2013) }\end{array}$ & $\begin{array}{l}\text { Relationship } \\
\text { between } \\
\text { psychological } \\
\text { capital, work } \\
\text { engagement, and } \\
\text { organizational } \\
\text { commitment }\end{array}$ & $\begin{array}{l}\text { Cross- } \\
\text { sectional } \\
\text { survey }\end{array}$ & $\begin{array}{l}\text { - There is a significant positive relationship } \\
\text { between psychological capital, work } \\
\text { engagement, and organizational } \\
\text { commitment. } \\
\text { - Work engagement is the only significant } \\
\text { predictor of organizational commitment. }\end{array}$ & $\begin{array}{l}\text { - The cross-sectional survey } \\
\text { design used cannot } \\
\text { determine the causality } \\
\text { among variables. } \\
\text { - Use of self-reported } \\
\text { questionnaire gave a ride to } \\
\text { response bias } \\
\text { - Small sample size }\end{array}$ \\
\hline 38. & $\begin{array}{l}\text { Kjellström, } \\
\text { Stålne, \& } \\
\text { Törnblom } \\
(2020)\end{array}$ & $\begin{array}{l}\text { Leadership } \\
\text { development }\end{array}$ & $\begin{array}{l}\text { Explorative } \\
\text { qualitative } \\
\text { study }\end{array}$ & $\begin{array}{l}\text { - The six ways of understanding leadership } \\
\text { development were: one's development, } \\
\text { fulfilling a leadership role, leader and } \\
\text { organizational development, personal } \\
\text { development, collective leadership } \\
\text { development, and human development. } \\
\text { - There is increasing complexity in } \\
\text { understanding leadership development }\end{array}$ & $\begin{array}{l}\text { - Focused on only six ways of } \\
\text { leadership development }\end{array}$ \\
\hline 39. & $\begin{array}{l}\text { Spillane } \\
(2005)\end{array}$ & $\begin{array}{l}\text { Distributed } \\
\text { leadership }\end{array}$ & $\begin{array}{l}\text { A critique on } \\
\text { existing } \\
\text { theoretical and } \\
\text { practical } \\
\text { knowledge on } \\
\text { distributed } \\
\text { leadership }\end{array}$ & $\begin{array}{l}\text { - The responsibility for leadership routines } \\
\text { in distributed leadership involves multiple } \\
\text { leaders } \\
\text { - Shared leadership, team leadership, and } \\
\text { democratic leadership are not synonyms of } \\
\text { distributed leadership. }\end{array}$ & $\begin{array}{l}\text { - The causal links between } \\
\text { distributed leadership, } \\
\text { instructional improvement, } \\
\text { and student outcome was not } \\
\text { established } \\
\text { - Limited empirical evidence } \\
\text { on the effectiveness of } \\
\text { distributed leadership. }\end{array}$ \\
\hline 40. & $\begin{array}{l}\text { Walker \& } \\
\text { Salt (2006) }\end{array}$ & $\begin{array}{l}\text { Emergent } \\
\text { paradigm } \\
\text { resilience }\end{array}$ & $\begin{array}{l}\text { Literature } \\
\text { review }\end{array}$ & $\begin{array}{l}\text { - Through a conceptual overview and case } \\
\text { studies, the study found that a resilient } \\
\text { world had five main attributes: diversity, } \\
\text { modularity, social capital, innovation, and } \\
\text { overlap in governance. }\end{array}$ & - Not indicated \\
\hline
\end{tabular}




\begin{tabular}{|c|c|c|c|c|c|}
\hline & & & & $\begin{array}{l}\text { - It defined social-ecological resilience as } \\
\text { the capacity of systems as households and } \\
\text { communities to respond to and deal with } \\
\text { disturbances, and bounce back without } \\
\text { affecting functioning or basic operations }\end{array}$ & \\
\hline 41. & $\begin{array}{l}\text { Wang, } \\
\text { Waldman, \& } \\
\text { Zhang } \\
(2014)\end{array}$ & $\begin{array}{l}\text { Shared leadership } \\
\text { and team } \\
\text { effectiveness }\end{array}$ & Meta-analysis & $\begin{array}{l}\text { - Shared leadership is positively related to } \\
\text { team effectiveness } \\
\text { - What is shared among members matters } \\
\text { when it comes to team effectiveness } \\
\text { - Shared leadership is more strongly related } \\
\text { to team attitudinal outcome and behavioral } \\
\text { processes compared to team performance }\end{array}$ & $\begin{array}{l}\text { - The number of studies } \\
\text { included was limited } \\
\text { - Inability to offer strong } \\
\text { causal inferences } \\
\text { - Only a few studies included } \\
\text { had a time lag }\end{array}$ \\
\hline 42. & $\begin{array}{l}\text { Wenger } \\
(2017)\end{array}$ & $\begin{array}{l}\text { Disaster } \\
\text { resilience and } \\
\text { how it is } \\
\text { connected to } \\
\text { long-term } \\
\text { organizational } \\
\text { resilience }\end{array}$ & $\begin{array}{l}\text { Systematic } \\
\text { review }\end{array}$ & $\begin{array}{l}\text { - The policy outcome indicates that } \\
\text { resilience can support resistance or } \\
\text { accommodative strategies } \\
\text { - Resilience is a measurable property } \\
\text { - Resilience is a process characterized by } \\
\text { adaptive capacity }\end{array}$ & $\begin{array}{l}\text { - The PPRR framework used } \\
\text { failed to distinguish between } \\
\text { measures conducive to long- } \\
\text { term resilience and those } \\
\text { conducive to maladaptive } \\
\text { outcomes }\end{array}$ \\
\hline 43. & $\begin{array}{l}\text { Yusof et al. } \\
(2012)\end{array}$ & $\begin{array}{l}\text { Knowledge } \\
\text { sharing in the } \\
\text { public sector }\end{array}$ & $\begin{array}{l}\text { Literature } \\
\text { review }\end{array}$ & $\begin{array}{l}\text { - Earlier approaches to knowledge sharing } \\
\text { have only focused on the factors that } \\
\text { influence it. The current study used a more } \\
\text { holistic and integrated approach. The } \\
\text { approach should draw together all critical } \\
\text { factors, including human (individual), } \\
\text { organization and technology factors that } \\
\text { come into play when it comes to } \\
\text { knowledge sharing. }\end{array}$ & $\begin{array}{l}\text { - The proposed model is } \\
\text { conceptual and therefore } \\
\text { lacks empirical evidence. }\end{array}$ \\
\hline
\end{tabular}

\section{Appreciating Shared Leadership}

Notably, all economic, political, and organizational systems depend on their leaders' effective and efficient guidance. The leaders create a corporate vision and ensure the cascading of the vision to the subordinates to avoid selfish interests that may override superordinate purposes. Leadership includes social influence (Bennis \& Nanus, 2007) driven by passion (Kotter, 2001), unlike the management associates who only embark on fulfilling the set organizational goals through formalized processes (Liphadzi, Aigbavboa, \& Thwala, 2017) as a factor of production whose competencies may affect project performance. Although leadership is a subset of management, both are critical in facilitating organizational performance (Jarad, 2012). Arguably, beyond management roles, leadership aims to promote fluidity and change within organizations, seeking continual adaptive change through influence.

Leadership is a social construct that is subjective depending on the "eyes of the beholder". Arguably, a person becomes a leader when followers perceive them as one (Northouse, 2016). Arguably, team performance is more of whether the actors see each other as leaders and followers. Top management's pivotal role encompasses designing strategies and enabling innovation among team players. Shared leadership influences such innovative team behavior (Muethel \& Hoegl, 2013) to improve a firm's performance (Daspit \& D'Souza, 2013). In other words, the above-stretched mandate is a shared effort that should involve the entire organization's cognitions and capabilities (Hambrick, 2007), helping a firm assimilate, transform, and exploit fresh ideas (Zahra \& George, 2002). Leaders are agents for improving team performance and effectiveness, the most critical ingredient for organizational resilience (Carson et al, 2007). The need for distributed leadership allowing for wide-range participation and collaborative decision-making (Devos et al., 2014). 
Collaborative leadership is critical during a crisis, aiming to empower and support teams to confront the day's challenges in a constructive way (Doffer et al., 2020) to maximize team efficacy (Bergman et al., 2012) through shared responsibility for shared outcomes (Hoch, 2013). The increased attention paid to shared forms of leadership suggests shared accountability through the distribution of responsibilities, thus substantially. Quality interaction between the leaders and followers involves social sharing of leadership, stretching leadership functions through an intentionally constructed interaction between multiple leaders (Devos et al., 2014). Shared leadership goes beyond the delegation of leadership tasks (Rayner \& Gunter, 2005). On the contrary, it involves stretching leadership resources by pooling together people's expertise, interactively making the leadership resource a group property (Yukl, 2002). Further, facilitating individual and collective efforts to accomplish shared objectives through dynamic, interactive leadership (Pearce \& Congner, 2003) that values environmental support, team members' working attitude, and communication with task interdependence (Bligh et al., 2006).

Pearce and Sims (2002) note that Shared leadership is the outcome of behavioral-based leadership theories that influence its theoretical structure, and directive Leadership that positions power or hierarchical influence of behavior in an organizational chart. It supports employee performance-based reward motivation and the sociology of Charisma: Empowering leadership that emphasizes self-development and enriching leadership skills (Pearce \& Sims, 2002).

\section{Shared Leadership Dimensions}

Yukl (2002) named "Shared Leadership" as a new paradigm of leadership that calls for a participatory approach to undertaking responsibilities and activities that follow the path of empowering followership and leadership. The distribution of leadership influence and the degree of leadership influence are the two main dimensions of shared leadership.

Bligh et al. (2006) extended the discussion by arguing that the leader's behavior is a critical pillar in encouraging employees to work in a team and employee attitude towards shared leadership to make it effective. A leader's behavior is a triad-dimensional that generally covers a sizable aspect of shared leadership; relations-oriented, task-oriented, and change-inclined attitude (Serban \& Boris, 2016; Yukl, 2002). The relations-oriented leadership emphasizes support to achieve a harmony that will help pursue goals efficiently (Yukl, 2002), highlighting work-flexibility and adaptability to cope with new ideas and changes.

\section{Forms of Shared Leadership}

To date, many scholars have taken divergent approaches to appreciate shared leadership. Some have focused on the art of sharing specific leadership styles; research is closely associated with the first distinguishing aspect of shared leadership, in which team affiliates accomplish the functions assumed by top leaders in the traditional setup (Pearce \& Sims, 2002). However, the combination of shared leadership with the many known leadership styles has reproduced a larger pool of potential constructs of shared leadership, for example, shared transformational, transactional, directive, charismatic, authentic, and empowering leadership (Wang et al., 2014). Shared transformational leadership and management, by exception, improve team resilience (Sommer et al., 2016). 
The second approach researchers understand what is to be shared and focus on the "overall" leadership (Wang et al., 2014) rather than capturing certain specific leader behavioral content, thus aggregating a person's leadership to the team level (Carson et al., 2007). For example, Carson et al. (2007) argue that the shared leadership score could be measured based on how teams rely heavily on most of their members. Shared leadership shifts the focus from person and position to process (Bolden et al., 2015). The "sharing" process may transpire across many functional roles proposed by the functional leadership theory (Morgeson et al., 2010), where manifold leadership functions happen. Shared leadership does not necessarily mean every team member performs all leadership functions. Characteristically, shared leadership is informal and ad hoc, forming an internal and informal leadership style riding on well-knit task interdependence at lower and higher levels.

\section{Operationalizing Shared Leadership}

In addition to the propagation of definitions around shared leadership, there are two ways to operationalize the construct (Wang et al., 2014). The "aggregation" or the "referent shift" approach may measure shared leadership by applying the traditional leadership scale. The multifactor leadership questionnaire shifts the source of leadership from the official leader to the team, aggregating the team members' ratings. Shared leadership takes five diverse behavioral strategies, that is, aversive, transactional, transformational, directive, and empowering. The aggregation approach fits with the key faces of shared leadership, taking it as an emergent property (Pearce \& Conger, 2003) unrealistically taking shared leadership pegged on the indistinguishable set of members with convergent attitudes (Carson et al., 2007): Hence its limitation. Another set of researchers (e.g., Carson et al., 2007) favor the social network approach, studying leadership as a shared activity, thus improving the appreciation of the repetitive leader-follower processes to facilitate the study of the team members' unique influence indexing as leadership centrality at the individual level. Shared leadership has been operationalized either as the density of leadership (Carson et al., 2007) or the decentralization of leadership. Density has been the most commonly used network index of shared leadership by measuring the degree to which the team relies on each teammate for leadership or decentralization of the shared leadership construct (DeRue et al., 2015).

\section{Resilience as a Resource}

The disciplines of ecology and sociology define resilience as the capacity of a system or a person to uphold its core purpose and integrity in exaggeratedly changing circumstances (Andrew \& Ann, 2012), allowing individuals to recover from hardship more powerfully than before. This general definition of resilience applies in a wide range of specific contexts, each providing insight for developing resilient systems and organizations (Langeland et al., 2016). Organizational executives should develop a culture and strategy that builds resilience through re-engineering resources (Langeland et al., 2016; Wu \& Chen, 2018). In behavioral science, people under stressful situations require resistance and support to improve their adaptation and response. Resilience is often used to describe a system or organism's competence to bounce back the following adversity in terms of capacity and time (Park et al., 2013), riding on a good psychological capital positioning through leadership (Simons \& Buitendach, 2013). Financial and Social capital are critical ingredients for achieving outcomes that work for all stakeholders 
(Gittell, 2006). However, another perspective stresses that high-performance work systems call for loyalty and commitment for individuals to work effectively (Park et al., 2013). Furthermore, if relationships help an organization bounce through a crisis, then it is essential to avoid harming relationships at such a critical time (Gittell, 2006).

Catastrophes present short-term, medium-term, and long-term challenges to organizations, thus calling for adequate control tasks stretching the world's imagination about potential damages and superior response strategies (Meyers, 2019), calling for leadership that fuels organizational learning (Daft, 2012). Resilient organizations do not limit the allocation of resources when dealing with threats that challenge their existence. Instead, they deploy available internal resources to guarantee the continuance of operations after a crisis (Gittell et al., 2006). Resilient firms prepare thoroughly for difficult situations, validating their preparedness in superior capacities to investigate, learn, and act against unknown disruptions. Furthermore, the firms cultivate motivation and other psychological resources of their employees not limited to self-efficacy, optimism, hope, and robustness to increase the chances of harvesting resiliency (Sutcliffe \& Vogus, 2003): Boosting employees' confidence to respond well during challenging situations. Possible indicators for measuring organizational resilience insinuated above centers around 1) Quality of organizational data for decision making hinging on availability, accuracy, real-time, relevant, coverage areas, use (decision-making), 2) Systems and Processes that support, analysis (business intelligence), the flow of information, communication, and agility - adaptability; and 3) Mutual Trust (Muethel \& Hoegl, 2013) exhibited in attention to results, no fear of conflict, accountability, and commitment.

\section{Shared Leadership and Corporate Resilience}

A fundamental prerequisite for acquiring new corporate knowledge hinges on the ability to recognize relevant knowledge based on prior firm's experiences (Zahra \& George, 2002) through a network diversity supports a broad scope of distinctive access to good governance (Faulkner et al., 2018). Corporate knowledge is not adequate if not assimilated throughout the organization: The firm's ability to analyze, interpret and comprehend acquired knowledge by the actors (Jansen et al., 2005). Information sharing and shared awareness increase efficiency and effectiveness after disruption (Langeland et al., 2016) to generate resilient systems. Shared leadership allows for the participation in integrating new knowledge, improving necessary mental models overall to build resilience pegged on much current literature review that expresses leadership as a shift to soft skills (Marques, 2013), going beyond charisma, eloquence, and extroversion. Employees have been found to incline towards soft-skilled leaders who demonstrate self-awareness, motivation, empathy, and self-regulation, as opposed to an exhibition of purely hard leadership skills such as intelligence, technical prowess, and rigor (Goleman, 2000): A complement of hard skills (Dixon et al., 2010). According to Nyman (2006), soft skills may not come too easy for leaders, calling for leaders to examine their techniques of relating to others, self-reflection, sensitivity to peoples' perceptions, humility, and influence.

Shared leadership manifests in a leader's ability to find relevance in a crisis, commonly known as crisis leadership. Crisis leadership includes team playing, strategic thinking, high transparency with stakeholders, speedy response to counter challenges through self-drive (Gilstrap et al., 2016). Shared leadership plays a critical role in fostering corporate 
accountability and success (Pearce et al., 2014), critical ingredients for team efficacy, and enhanced agency behavior at all organizational levels (Magnus, Robert, \& Steve, 2019). A selfled leader has a higher capability of developing employees' positivity, especially on disaster risk management practices through sharpened organizational learning (Kumiko \& Fernando, 2010). A self-led leader positivity improves an enthusiastic and cheerful mind, enhancing task performance (Wright, 2014), hence organizational resilience through employee commitment to the organization's mission and mandate. Dependable organizations spur employee commitment to continuous improvement to deal with change: For example, through risk management programs that improve the firm's resilience and citizenship behavior (Happy et al., 2016) and disaster preparedness (Barquet et al., 2016).

\section{Theoretical Review}

Transactional leadership theory, complexity theory, behavioral theory, transactional theory, and multi-stakeholder theory are critical pillars for the current study. The theories emphasize that empowering the organization to remain relevant and focused remains a critical pillar to confront the day's challenges. The leaders may demonstrate their superior economic behavior by passively drawing consequences from changing environments and changing the given circumstances. The corporate sustainability school of thought emphasizes that leaders should configure the organization to meet society's broader expectations. Arguably, sustainability management calls for organizations to develop new ways of creating a robust and resilient economy.

\section{A call for a New Theoretical Model}

Based on the above observations, the study proposes the following model to guide future studies regarding the construct of shared leadership and organizational resilience.

Proposition 1: The fluidity of the operating environment may propel the urgency of shared leadership behavior, calling for collaboration to steer the firm to greater resilience.

As displayed in Figure 1, the framework provides a broad spectrum of studying the interplay of variables that would improve organizational resilience, noting that shared leadership may occur differently depending on the context. For example, groups may experience stagnation when a chaotic state seems very far, depriving the group of the necessary stimulation to animate its work (Virginia, 2016). The decision-making process and subsequent decision outcomes follow different logics based on the decision-makers differing perceive about an uncertain future: Experience brings forth capabilities and the impetus to take action, evaluate risks, and allocate resources to address uncertainty. The leaders' responsibilities should help a firm assimilate, transform, and exploit fresh ideas by increasing a firm's absorptive capacity (Zahra \& George, 2002) as a matter of urgency and anticipation of a mutually beneficial reward system. 


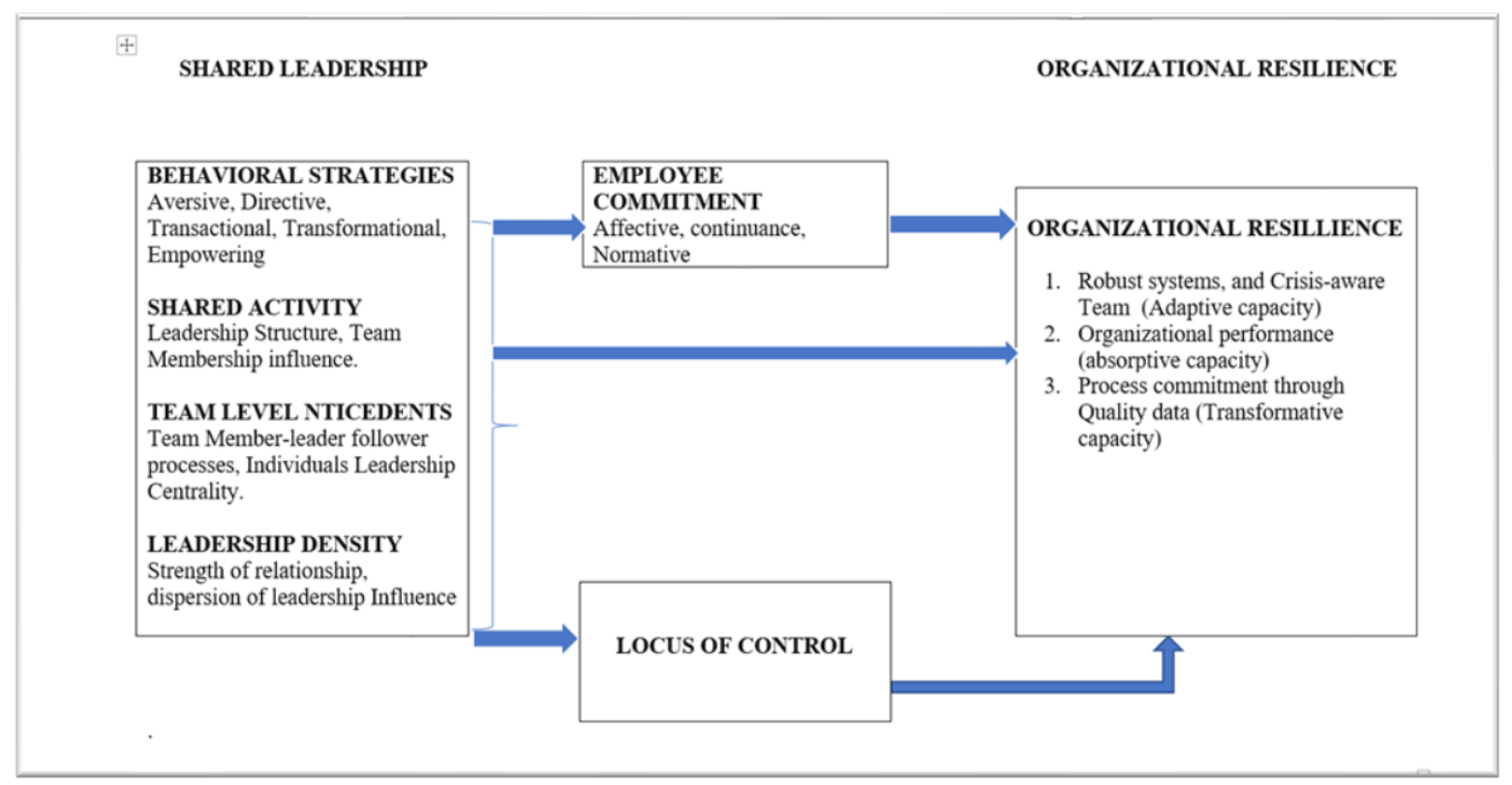

Figure 2. Shared leadership, and organizational resilience

Proposition 2: Deployment of the shared leadership strategy hinging on shared construction of corporate direction will positively affect behavioural efficacy necessary to improve the various dimensions of a firm's resilience.

A right balance between flexible workers and distributed decision-making; technical personnel lead by a centralized decision-making organ would increase appropriate organizational reactions during and after a crisis (McLeod et al., 2016). Relevant training on response to specific threats and still maintains flexibility in disaster response procedures is an uphill task calling for organizations to address a combination of specific and general risks. The framework advocates for the increased scope that involves training on unknown threats through increased follower-commitment hinging on an enhanced locus of control. The need for structures that improve the quality of dyadic leader-follower relations grows a committed and empowered joint workforce ready to act in favour of the organization's long-term advancement.

Proposition 3: Deployment of the shared leadership strategy that improves the internal organization environment will positively affect employee and organizational commitment, thus improving the various dimensions of a firm's resilience.

This calls for a leader to configure an organization to deliver an internal team environment with task cohesion, which predicts shared leadership and task satisfaction. Task satisfaction increases efficacy in execution, thus superior organizational efficacy. Organizational dependability influences commitment to building resilient teams.

Proposition 4: Deployment of the shared leadership strategy that improves Team member's leader-follower processes and individuals' leadership centrality will positively affect the employee's assertiveness and positivism to spur resilience. 
A dyadic leader-follower relationship forms the overall leadership structure in a team. Decentralized leadership allows teams to influence each other to act, thus raising their cognitive awareness on aspects that would negatively affect firm performance, making everyone a champion for risk awareness through increased density of how each actor relies on each teammate for leadership (Carson et al., 2007). As a result, risk-aware people enhance a firm's adaptability and resilience.

Proposition 5: Deployment of the shared leadership strategy that improves Team member's locus of control would harvest organization resilience through behavior efficacy.

The locus of control is critical as members of an organization act to create organizational resilience. Although employee commitment harvests superior organizational performance, the psychological perspective that conceives organizational behavior and human behavioral actions is a function of personal dispositions and capacities. Notably, the intensity of stress reduces as the actor focuses on the locus of control, thus increasing the effectiveness of an intrinsic reward signal to spur the agent to explore its situation and learn skills (Pathak et al., 2017).

Proposition 6: Deployment of the shared leadership strategy that improves leadership dispersion and Team member's relationships increases the focus on the organization's controls to provide Quality data, Robust systems, and Process Commitment will elicit disaster-prepared organizations, an antecedent of organizational resilience.

Resilient organizations ride on systems that notice underlying vulnerability and create robust strategies for handling the wide-ranging effects of catastrophes. The above superior behavioral focus would improve organizational efficacy to create processes that guarantee quality information to guide resilience-based decisions.

\section{Conclusion}

Shared leadership can be situated within the broader concept of team leadership, including vertical, horizontal, and centralized forms of leadership aimed at combating increased complexity and ambiguity of tasks in parallel with the increasing pressure to respond more promptly to market conditions and challenges through superior decision-making (Hoch \& Dulebohn, 2017). Various studies, however, reveal that shared leadership is not a panacea for all organizational problems. Through limited research, there are diverse perspectives of defining resilience; resilience should support adaptation beyond space and time.

Organizational strength is a derivative of a complex interplay of factors at different levels (Kumiko \& Fernando, 2010) to navigate a complex operating environment (Gibbs, 2019). Performance feedback is a driver for organizational learning and improved organizational resilience. Agile and integrated coordination among stakeholders would ensure reliable information runs through the organization to create the necessary calm for decision-making and optimism. Shared leadership plays a critical role in fostering corporate accountability and success (Pearce et al., 2014). The shared leadership spurs exceptional outcomes and improved capabilities to solve complex problems (Nathaniel et al., 2019): Critical pillars for building resilient brands. 


\section{References}

Andrew, Z., \& Ann, M. H. (2012). Resilience: Why things bounce back. Simon and Schuster, Inc. New York.

Barquet, K., Osbeck, M., Thomalla, F., \& Boyland, M. (2016). Using learning to harness socialand organizational culture for disaster risk reduction. Working paper, 2016-10. https://doi.org/10.13140/RG.2.2.10706.96962

Bendell, J., \& Little, R. (2015). Seeking sustainability leadership. The Journal of Corporate Citizenship, 60, 13-26.

Bennis, W., \& Nanus, B. (2007) Leaders: Strategies for taking charge. Collins business

Bergman, J. Z., Rentsch, J. R., Small, E. E., Davenport, S. W., \& Bergman, S. M. (2012). The shared leadership process in decision-making teams. The Journal of Social Psychology, 152 (1), 17-42.

Bligh, M. C., Pearce, C. L., \& Kohles, J. C. (2006). The importance of self-and shared leadership in team-based knowledge work: A meso-level model of leadership dynamics. Journal of Managerial Psychology, 21(4), 296-318.

Bolden, R., Jones, S., Davis, H., \& Gentle, P. (2015). Developing and sustaining shared leadership in higher education. Leadership Foundation Higher Education.

Carson, J., Tesluk, P., \& Marrone, J. (2007). Shared leadership in teams: An investigation of antecedent conditions and performance. The Academy of Management Journal, 50(5), 1217-1234.

Cobanoglu, N. (2020). Investigation of shared leadership and organizational commitment in primary and secondary schools: Malatya case. International Journal of Educational Methodology, 6(3), 613-629. https://doi.org/10.12973/ijem.6.3.613

Cullen-Lester, K. L., \& Yammarino, F. J. (2016). Collective and network approaches to leadership: Special issue introduction.

Daft, R. (2012). Organization theory and design (12th Ed.). Cincinnati: Southwestern. (ISBN: 9781285866345).

Daspit, J. J., \& D'Souza, D. E. (2013). Understanding the multi-dimensional nature of absorptive capacity. Journal of Managerial Issues, 25, 299-316.

DeRue, D. S., Nahrgang, J. D., \& Ashford, S. J. (2015). Interpersonal perceptions and the emergence of leadership structures in groups: A network perspective. Organization Science, 26(4), 1192-1209.

Devos, G., Tuytens, M., \& Hulpia, H. (2014). Teachers' organizational commitment: Examining the mediating effects of distributed leadership. American Journal of Education, 120(2), 205-231.

Dixon, J., Belnap, C., Albrecht, C., \& Lee, K. (2010). The importance of soft skills. Corporate Finance Review, 14(6), 3538.

Doffer, A., Reitsma, D., Reitsma, J., Sinning, P., \& Bekkers, F. (2020). Divided we stand? Towards post-corona leadership. (pp. 19-31, Rep.). Hague Centre for Strategic Studies.

Erkutlu, H. (2012). The impact of organizational culture on the relationship between shared leadership and team proactivity. Team Performance Management: An International Journal, 8(1/2), 102119. https://doi.org/10.1108/13527591211207734

Faulkner, L., Brown, K., \& Quinn, T. (2018). Analyzing community resilience as an emergent property of dynamic socialecological systems. Ecology and Society, 23(1).

Fernandez, S., \& Moldogaziev, T. (2011). Empowering public sector employees to improve performance: Does it work? The American Review of Public Administration, 41(1), 23-47.

Gemma, D., \& Aaron, D. S. (2020). Leadership in a crisis: Responding to the coronavirus outbreak and future challenges. McKinsey COVID-19 executive briefing. Retrieved from https://www.mckinsey.com/

Gibbs, L., Press, F., \& Wong, S. (2019). Complexity leadership theory: A framework for leading in Australian early childhood education settings. In P. Strehmel, J. Heikka, E. Hujala, J. Rodd, \& Waniganayake, M. (Eds.), Leadership in early education in times of change: Research from five continents (pp. 173-186). Opladen; Berlin; Toronto: Verlag Barbara Budrich. https://doi.org/10.2307/j.ctvmd84fc.16

Gilson, L., Ellokor, S., Lehmann, U., \& Brady, L. (2020). Organizational change and everyday health system resilience: lessons from Cape Town, South Africa. Social Science and Medicine, 266, 113407.

Gilstrap, C., Gilstrap, C., Holderby, K., \& Valera, K. (2016). Sense-giving, Leadership, and nonprofit crises: How nonprofit leaders make and give sense to organizational crisis. Voluntas: International Journal of Voluntary and Nonprofit Organizations, 27(6), 2787-2806.

Gittell, J. (2006). Layoffs and organizational resilience: Lessons for workers, managers, and investors. Perspectives on Work, $10(1), 6-8$.

Gittell, J. H., Cameron, K., Lim, S., \& Rivas, V. (2006). Relationships, layoffs, and organizational resilience: Airline industry responses to September 11. The Journal of Applied Behavioral Science, 42(3), 300-329. 
Goksoy, S. (2016). Analysis of the relationship between shared leadership and distributed leadership. Eurasian Journal of Educational Research, 65, 295-312. http://dx.doi.org/10.14689/ejer.2016.65.17

Goldsmith, M. (2010). Sharing leadership to maximize talent. Harvard Business Review. Retrieved from https://hbr.org/2010/05/sharing-leadership-to-maximize/

Goleman, D. (2000). Emotional intelligence: Issues in paradigm building. In D. Goleman \& C. Cherniss (Eds.), The emotionally intelligent workplace: how to select for, measure, and improve emotional intelligence in individuals, groups, and organizations. San Francisco, CA: Jossey-Bass.

Grote, G. (2019) Leadership in resilient organizations. In S. Wiig \& B. Fahlbruch (Eds.), Exploring resilience (pp. 59-67). Springer: Briets in Applied Sciences and Technology.

Hambrick, D. C. (2007). Upper echelons theory: An update. Academy of Management Review, 32, 334-343.

Happy, P., Umesh, K., \&Pooja, G. (2016) Employee resilience and OCB: Mediating effects of organizational commitment, Vikalpa, 41(4), 308-324. https://doi.org/10.1177/0256090916672765

Hoch, J. E. (2013). Shared leadership and innovation: The Role of vertical leadership and employee integrity. Journal of Business and Psychology, 28(2), 159-174.

Hoch, J. E., \& Dulebohn, J. H. (2017). Team personality composition, emergent leadership, and shared leadership in virtual teams: A theoretical framework. Human Resource Management Review, 27(4), 678-693.

Houghton, J. D., Pearce, C. L., Manz, C. C., Courtright, S, \& Stewart, G. L. (2015). Sharing is caring: Toward a model of proactive caring through shared leadership. Human Resource Management Review, 25(3), 313-327.

Jansen, J. J., Van Den Bosch, F. A., \& Volberda, H. W. (2005). Managing potential and realized absorptive capacity: how do organizational antecedents matter? Academy of management journal, 48(6), 999-1015.

Jarad, G. H. (2012). The construction manager leading characteristics for the success of construction projects in the Gaza Strip (Unpublished master's thesis). The Islamic University of Gaza. Retrieved from http://hdl.handle.net/20.500.12358/19101

Kjellström, S., Stålne, K., \& Törnblom, O. (2020). Six ways of understanding leadership development: An exploration of increasing complexity. Leadership, 16(4), 434-460.

Kotter, J. P. (2001). Leading change: A conversation with John P Kotter, 25(1), MCB UP.

Kumiko, O., \& Fernando, J. B. (2010). Influencing factors for Resilience in organizations - a case study in a transformation industry company. Paper presented at the Xvi International Conference on Industrial Engineering and Operations Management. Brazil. Retreived from http://www.abepro.org.br/biblioteca/enegep2010_TI_ST_130_833_16405.pdf

Langeland, K., Manheim, D., McLeod, G., \& Nacouzi, G. (2016). Definitions, characteristics, and assessments of resilience. In how civil institutions build resilience: Organizational practices derived from academic literature and case studies (pp. 5-10). RAND Corporation.

Liang, B., \& Gu, Q. X. (2016, August). Shared leadership and creativity in knowledge-worker teams: a multilevel motivational perspective. Paper presented at the 76th Annual Meeting of the Academy of Management, Anaheim, California, USA.

Liphadzi, M., Aigbavboa, C., \& Thwala, W.D. (2017). A theoretical perspective on the difference between leadership and management. Procedia Engineering, 196, 478-482.

Locke, E. A., Srivastava, A., \& Bartol, K. M. (2006). Empowering leadership in management teams: Effects on knowledge sharing, efficacy, and performance. Academy of Management Journal, 49(6), 1239-1251.

Lord, R. G., Day, D. V., Zaccaro, S. J., Avolio, B. J., \& Eagly, A. H. (2017). Leadership in applied psychology: three waves of theory and research. Journal of Applied Psychology, 102, 434-451.

Magis, K. (2010). Community resilience: an indicator of social sustainability. Society and Natural Resources. 23(5), 401-16.

Magnus, L., Robert, H., \& Steve, K. (2019). It's the organization that is wrong': Exploring disengagement from organizations through leadership development. Leadership, 16(2), 41-162.

Marques, J. (2013). Understanding the strength of gentleness: Soft-skilled leadership on the rise. Journal of Business Ethics, 116(1), 163-171.

McLeod, G., Nacouzi, G., Dreyer, P., Eisman, M., Hura, M., Langeland, K., \& Torrington, G. (2016). Resilience and civil institutions. In Enhancing Space Resilience Through Non-Materiel Means (pp. 7-14).

Meyers, T. (2019). Ten disasters that changed the world. Direct Relief. Retrieved from https://www.directrelief.org/

Morgeson, F. P., DeRue, D. S., \& Karam, E. P. (2010). Leadership in teams: A functional approach to understanding leadership structures and processes. Journal of Management, 36(1), 5-39. 
Muethel, M., \& Hoegl, M. (2013). Shared leadership effectiveness in independent professional teams. European Management Journal, 31(4), 423-432.

Muthimi, J. K., \& Kilika, J. M. (2018). Leadership strategy, behavioural focus and firm performance: A review of literature. International Business Research, 11(11), 143-163.

Nathaniel, H., Carlos, R. C., \& Jesse, D. (2019). Does sharing leadership actually work? An evaluation of the benefits and drawbacks of shared leadership. Journal of Education, Innovation, and Communication, 1(1), 31- 41.

Nicolaides, V. C., LaPort, Chen, T. R, Tomassetti, A. J., Weis, E. J., \& Zaccaro, S. J. (2014). The shared leadership of teams: A meta-analysis of proximal, distal, and moderating relationships. The Leadership Quarterly, 25(5), 923-942.

Northouse, P. G. (2016). Leadership: Theory and practice (7th ed.). Thousand Oaks, CA: Sage.

Nyman, M. (2006). Want to be a topflight leader? Hone your people- skills. Chemical Engineering, 113(8), 63-66.

O'Toole, J., Galbraith, J., \& Lawler, E. E. (2002). When two (or more) heads are better than one: The promise and pitfalls of shared leadership. California Management Review, 44(4), 65-83.

Park, J, Seager, T. P., Rao, P. S., Convertino, M., \& Linkov, I. (2013). Integrating risk and resilience approaches to catastrophe management in engineering systems. Risk Analysis, 33(3), 356-367.

Parris, D., \& Peachey, J. (2013). A systematic literature review of servant leadership theory in organizational contexts. Journal of Business Ethics, 113(3), 377-393.

Pathak, D., Agrawal, P., Efros, A. A., \& Darrell, T. (2017). Curiosity-driven exploration by self-supervised prediction. Proceedings of International Conference on Machine Learning, 2778-2787. Cornell University. arXiv: 1705.05363

Paul, H., Bamel, K., B., \& Garg, P. V. (2016). Employee resilience and OCB: Mediating effects of organizational commitment. Vikalpa: The Journal for Decision Makers, 41(4), 308-324.

Pearce, C. L. (2007). The future of leadership development: the importance of identity, multi-level approaches, selfleadership, physical fitness, shared leadership, networking, creativity, emotions, spirituality and on-boarding processes. Management Department Faculty Publications. https://digitalcommons.unl.edu/managementfacpub/73

Pearce, C. L., \& Conger, J. A. (Eds.) (2003). Shared leadership: Reframing the hows and whys of leadership. Thousand Oaks, CA: SAGE

Pearce, C. L., \& Sims, H. P., Jr. (2002). Vertical versus shared leadership as predictors of the effectiveness of change management teams: An examination of aversive, directive, transactional, transformational, and empowering leader behaviors. Group Dynamics: Theory, Research, and Practice, 6(2).

Pearce, C., Wassenaar, C., \& Manz, C. (2014). Is shared leadership the key to responsible leadership? Academy of Management Perspectives, 28(3), 275-288.

Rayner, S., \& Gunter, H. (2005). Rethinking leadership: perspectives on remodeling practice. Educational Review, 57(2), 151-161. https://doi.org/10.1080/0013191042000308332

Sandesh, K., \& Sharma, N., S. (2020). Hospital preparedness and resilience in public health emergencies at district hospitals and community health centres. Journal of Health Management, 22(2), 146-156.

Scott-Young, C. M., Georgy, M., \& Grisinger, A. (2019). Shared leadership in project teams: An integrative multi-level conceptual model and research agenda. International Journal of Project Management, 37(4), 565-581.

Serban, I., \& Boris, C. (2016). Résiliences: ressemblances dans la diversité. ISBN: 2738134491, 9782738134493. Retrieved from https://books.google.co.ke/

Sharma, S., \& Sharma, S. (2020). Probing the links between team resilience, competitive advantage, and organizational effectiveness: Evidence from information technology industry. Business Perspectives and Research, 8(2), 289-307.

Simons, C., \& Buitendach, H. (2013). Psychological capital, work engagement, and organisational commitment amongst call centre employees in South Africa. SA Journal of Industrial Psychology/SA Tydskrif vir Bedryfsielkunde, 39(2), Art. \#1071, 12 pages.

Sinclair, A. (2014). A feminist case for leadership. In J. Damousi, K. Rubenstein, \& M. Tomsic (Eds.), Diversity in Leadership: Australian women, past and present (pp. 17-36). ANU Press.

Sommer, S. A, Howell, J. M., \& Hadley, C. N. (2016). Keeping positive and building strength: The role of affect and team leadership in developing resilience during an organizational crisis. Group and Organization Management, 41(2), $172-202$. https://doi.org/10.1177/1059601115578027

Spillane, J. (2005). Distributed leadership. The Educational Forum, 69(2), 143-150.

Sutcliffe, K. M., \& Vogus, T. J. (2003). Organizing for resilience. In K. S. Cameron, J. E. Dutton, \& R. E. Quinn (Eds.), Positive organizational scholarship: Foundations of a new discipline (pp. 94-110). San Francisco, CA: Berrett-Koehler. 
Virginia, B. (2016). Chaos theory and group psychotherapy 15 years later. Group, 40(1), 9-15.

Walker, B., \& Salt, D. (2006). Resilience thinking: sustaining ecosystems and people in a changing world. Island Press, Washington, D.C., USA.

Wang, D., Waldman, D. A., \& Zhang, Z. (2014). A meta-analysis of shared leadership and team effectiveness. Journal of Applied Psychology, 99(2), 181.

Wenger, C. (2017). The oak or the reed: How resilience theories are translated into disaster management policies. Ecology and Society, 22(3).

Wright, T. (2014). Putting your best "face" forward: The role of emotion-based well-being in organizational research. Journal of Organizational Behavior, 35(8), 1153-1168.

Wu, C. M., \& Chen, T. J. (2018). Collective psychological capital: Linking shared leadership, organizational commitment, and creativity. International Journal of Hospitality Management, 74, 75-84.

Yukl, G. (2002). Leadership in Organizations. Thousand Oaks, CA: Sage Publication

Yusof, Z. M., Ismail, M. B., Ahmad, K., \& Yusof, M. M. (2012). Knowledge sharing in the public sector in Malaysia: a proposed holistic model. Information Development, 28(1), 43-54.

Zahra, S. A., \& George. G. (2002). Absorptive capacity. A Review, Reconceptualization, and Extension of Management Review, 27(2), 185-203.

\section{Acknowledgments}

The author would like to thank Dr. Kilika for his unmeasured support and the collaboration of PAC university professors and colleagues in this journey.

\section{Disclosure Statement}

No potential conflict of interest was reported by the authors.

\section{Funding Acknowledgments}

Not applicable.

\section{Open Access}

The International Journal of Organizational Leadership publishes open access articles under the terms of the Creative Commons Attribution (CC BY) License, which permits use, distribution, and reproduction in any medium, provided the original work is properly cited. 